\title{
FACTORS AFFECTING QUALITY OF TILLAGE WITH DISC HARROW
}

\author{
Vladyslav Zubko ${ }^{1}$, Sergii Sokolik ${ }^{1}$, Tetiana Khvorost ${ }^{2}$, Valentyna Melnyk ${ }^{2}$ \\ ${ }^{1}$ Sumy National Agrarian University, Ukraine; \\ ${ }^{2}$ National University of Life and Environmental Sciences of Ukraine, Ukraine \\ zubkovladislav@ukr.net, sokolik1009@gmail.com, khvorost.t83@gmail.com, vim2607@gmail.com
}

\begin{abstract}
Disc tillage allows to solve important agronomic tasks: destruction of weeds, pests and pathogens of plants; preservation and increase of moisture reserves in the soil; activation of microorganisms; incorporation the plant residues and mineral fertilizers into soil; providing the necessary conditions for high-quality subsequent tillage operations. The aim of this study was to determine the impact on the quality of tillage with disc harrows of such parameters as the machine speed, set depth of tillage, direction of movement of the harrow relative to the furrow. During the field experiments, such indicators of tillage quality as deviation of the tillage depth, field surface alignment, furrow bottom profile, percentage of plant residue incorporation were studied. The tillage quality was investigated in dependence on the working speed $\left(2.5 ; 3.1 ; 3.6 ; 4.2 \mathrm{~m} \cdot \mathrm{s}^{-1}\right)$, set depth of tillage $(7,10$ and $14 \mathrm{~cm}$ ), direction of movement (along and at an angle to the furrow line). The analysis of the obtained data made it possible to determine the parameters of the speed of the tillage aggregate, the depth of cultivation and the direction of movement in the field, which allow to perform disc tillage in compliance with agricultural requirements. The values of deviations in the depth of cultivation satisfied the agricultural requirements in both directions of movement of the unit, except for cultivation to a depth of $14 \mathrm{~cm}$. The values of the furrow bottom profile were better when moving at an angle of $35^{\circ}$ to the furrow line. For all tillage depths, the highest percentage of plant residues incorporation $(46.4 \%, 59.3 \%, 65.7 \%)$ was observed at speed $3.6 \mathrm{~m} \cdot \mathrm{s}^{-1}$.
\end{abstract}

Keywords: disc harrow; disc tillage; tillage quality; tillage depth; operation speed.

\section{Introduction}

Disc tillage solves important agronomic tasks: control of weeds, pests and pathogens of cultivated plants; preservation and accumulation of soil moisture; activation of microbiological processes; incorporation of post-harvest residues and fertilizers; preparation for high-quality execution of further operations of the main tillage $[1 ; 2]$.

The quality of operation of disc machines depends on the correct choice of their optimal parameters and operating modes, which are completely determined not only by their design features, but also by the operating conditions. Moreover, within the same soil-climatic zone, under the conditions of different predecessors, a wide range of changes in most soil properties is often the main reason for the violation of the quality of work [2-4].

Often in Ukraine discing of the soil precedes the sowing of winter crops and is carried out after harvesting such crops as corn, sunflower, rapeseed and other crops. In such conditions, soil discing is carried out to a depth of $15 \mathrm{~cm}$. The deviation from the discing depth should not exceed $\pm 3 \mathrm{~cm}$. Soil fractions up to $5 \mathrm{~cm}$ in size should be at least $80 \%$. Lumps larger than $10 \mathrm{~cm}$ are not allowed. The degree of incorporation of plant residues during disc tillage should be at least $60 \%$. The height of the ridges on the field surface should not exceed $5 \mathrm{~cm}$, the height of the ridges at the bottom of the furrow (furrow bottom profile) after one pass of the disc harrow $-5 \mathrm{~cm}$, and after two $-4 \mathrm{~cm}$. The degree of weed pruning should be $95-100 \%[5 ; 6]$.

Important factors that have a significant impact on the quality of disc tillage are the shape and size of the discs, their placement on the frame and orientation in the soil, the weight of the machine. However, in addition to these parameters, the modes of operation of machines (working speed, set depth of cultivation, direction of movement in the field) and soil conditions (soil type, soil density, soil hardness and moisture, amount of crop residues) have a significant impact on the quality indicators $[1 ; 3-8]$.

There are large number of researches in the draft force, fuel consumption and soil properties, but the post-harvest tillage quality level is not accented.

The tillage depth is the primary determinant of the power amount required to pull an implement, with the speed often having a significant effect $[9 ; 10]$. Kogut et al. established that the draft demand depends on the angle of the harrow disc [11]. According to Serrano et al., it is possible to use a lower attack angle of the disc harrow at a higher speed with no visible difference in soil tilt [12]. 
Damanauskas et al. in their study determined the optimal tillage performances and the fuel consumption, what is required to achieve the preferred level of stubble tillage in loam and clay loam soil after winter oilseed rape harvest. The incorporation of residues was more dependent on the working speed and angle of the disc than on the tillage depth. An increase in the speed and depth of soil cultivation led to an increase in the percentage of incorporated plant residues [13]. Studies conducted by Liu and Kushwaha also indicated that higher speed of the tillage operation will reduce the residue cover [14].

Post-harvest tillage has a significant impact on the next following agricultural operation, so it is important to do it properly. That is why the quality of this primary processing must be in line with the agronomic requirements, because the process of straw decomposition is faster when the incorporation quality is better [15].

The efficiency of using the machine affects both the final yield and the cost of production. An urgent task is to reduce the cost of disc tillage, while maintaining the productivity of the machine and ensuring the quality of the operation. Therefore, it is important to conduct appropriate research and develop recommendations for effective use of disc tillage machines.

The aim of this study is to determine the impact on the quality of tillage with disc harrows of such parameters as the machine speed, set depth of tillage, direction of movement of the harrow relative to the furrow.

\section{Materials and methods}

Research was done in the northeast part of Ukraine on black soil at the Institute of Agriculture of the Northeast NAAS in the fall of 2019. The treatments were performed in corn stubble which height was $30 \pm 2 \mathrm{~cm}$. Tests were done on the same day after corn harvest. The condition of soil was evaluated before the experiment. The Penetrometer Pn-10 was used for penetration resistance measurement. The mean penetration resistance at $10 \mathrm{~cm}$ was $1.35 \mathrm{MPa}$ and $1.9 \mathrm{MPa}$ at $15 \mathrm{~cm}$. Water content of the soil was determined by the gravimetric method; the mean soil water content at the soil surface $10 \mathrm{~cm}$ was $18 \%$. The study was performed using a medium power tractor MTZ-1025 in combination with a disc harrow. The tractor's working speed was achieved by changing varied gears. Studies of harrow operation were performed in different directions of movement relative to the row of plants: along the row and at an angle of $35^{\circ}$. The tests were accomplished at a fixed disc angle $20^{\circ}$, the tillage depth at 7,10 and $14 \mathrm{~cm}$, the harrow was towed at operation speed $2.5 ; 3.1 ; 3.6 ; 4.2 \mathrm{~m} \cdot \mathrm{s}^{-1}$. The compact disc harrow "Dukat-2.5" is constructed from two rows of spherical discs with a diameter of $566 \mathrm{~mm}$ and a roller. Working width of the machine is $2.5 \mathrm{~m}$. Determination of the quality indicators was conducted in accordance with standard methods [16-18].

For assessment of plant residue incorporation quality, the weight method was used. All residues (corn stubble, other residues and weeds) were collected with five replications from the soil surface in the frame of $0.25 \mathrm{~m}^{2}(50 \times 50 \mathrm{~cm})$ to determine the background before tillage. The quality of plant residues incorporation was estimated by the ratio of the plant residue mass incorporated into soil after tillage and the plant residue mass before tillage.

The harrowing depth was measured using a specially made metal probe with graduations. The probe was immersed in the ground until it contacts the sole formed by the disc. After that, the mark on the probe scale was assessed and recorded in the working materials. The data obtained were used to analyze the deviation of the average actual processing depth from the specified adjustment.

Determination of the height of the ridges after tillage by machines with disc working bodies was carried out using a 2-meter rod laid on the ridges and a ruler, which was installed on the bottom of the furrow. The obtained data was recorded in the working materials.

Data analysis and graphing were performed using Microsoft Office Excel graphical editor.

\section{Results and discussion}

The results of the research presented in Fig. 1. show the change of deviation from the set depths of cultivation depending on the speed, when the machine was moving along the line. The values of the deviations increased with increasing the set depth. For all depths of cultivation $(7 \mathrm{~cm}, 10 \mathrm{~cm}, 14 \mathrm{~cm})$ the largest deviations $(8.2 \%, 12 \%, 28.0 \%)$ were recorded at a harrow speed of $3.6 \mathrm{~m} \cdot \mathrm{s}^{-1}$, and the smallest values of deviations were observed at a speed of $3.1 \mathrm{~m} \cdot \mathrm{s}^{-1}(-2.9 \%, 1.4 \%, 20.7 \%)$. 


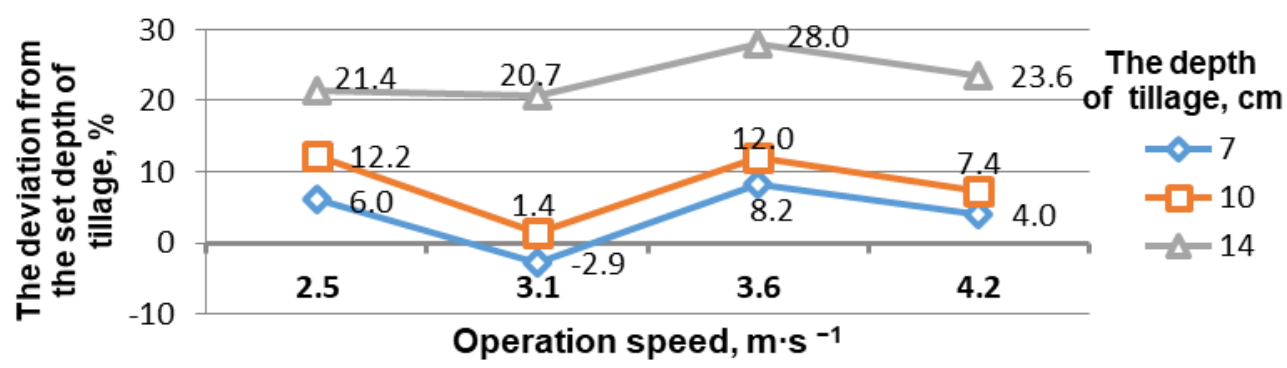

Fig. 1. Dependence of deviation of the set depth of tillage on operation speed of the harrow when moving along a row

Fig. 2 shows how the deviations from the set depths of cultivation changed depending on the speed in the direction of the movement of the harrow at an angle of $35^{\circ}$ to the row. The values of the deviations increased with increasing the depth of cultivation. For all depths of cultivation $(7 \mathrm{~cm}, 10 \mathrm{~cm}, 14 \mathrm{~cm})$ the smallest deviations $(-4 \%,-2.6 \%, 17.1 \%)$ were recorded at a harrow speed of $3.6 \mathrm{~m} \cdot \mathrm{s}^{-1}$. Negative deviations for the working depths of 7 and $10 \mathrm{~cm}$ indicate that the harrow discs were deeper than the set limits when adjusting the implement.

It should be noted that in both directions of movement of the machine the values of deviations from the set depth of cultivation did not exceed the established agricultural requirements of $20 \mathrm{~mm}$, except for cultivation to a depth of $14 \mathrm{~cm}$, when moving along the row. The smallest deviation $(1.4 \%)$ was observed, when the machine was moving along the row at a speed of $3.1 \mathrm{~m} \mathrm{~s}^{-1}$ for a set depth of $10 \mathrm{~cm}$.

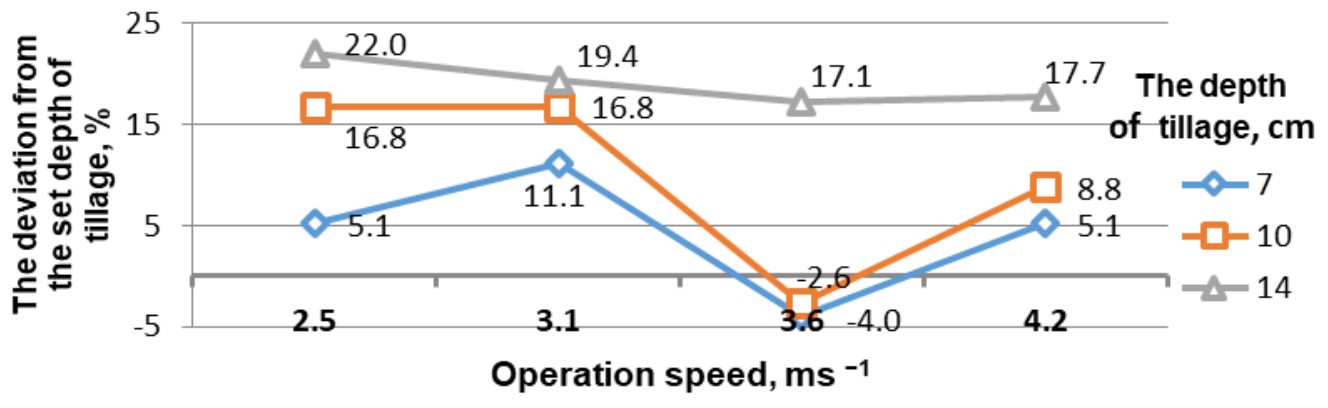

Fig. 2. Dependence of deviation of the set depth of tillage on operation speed of the harrow when moving at an angle of $35^{\circ}$ to a row

According to agricultural requirements, the degree of incorporation of plant residues during disc tillage should be at least $60 \%[4 ; 5]$. Fig. 3 shows how the number of incorporated plant residues changed depending on the speed, when the harrow moved along the row. The percentage of incorporated plant residues increases with increasing the harrow operation speed from $2.5 \mathrm{~m} \cdot \mathrm{s}^{-1}$ to $3.6 \mathrm{~m} \cdot \mathrm{s}^{-1}$. At an operation speed of $4.2 \mathrm{~m} \cdot \mathrm{s}^{-1}$, a decrease in the proportion of incorporated residues was observed.

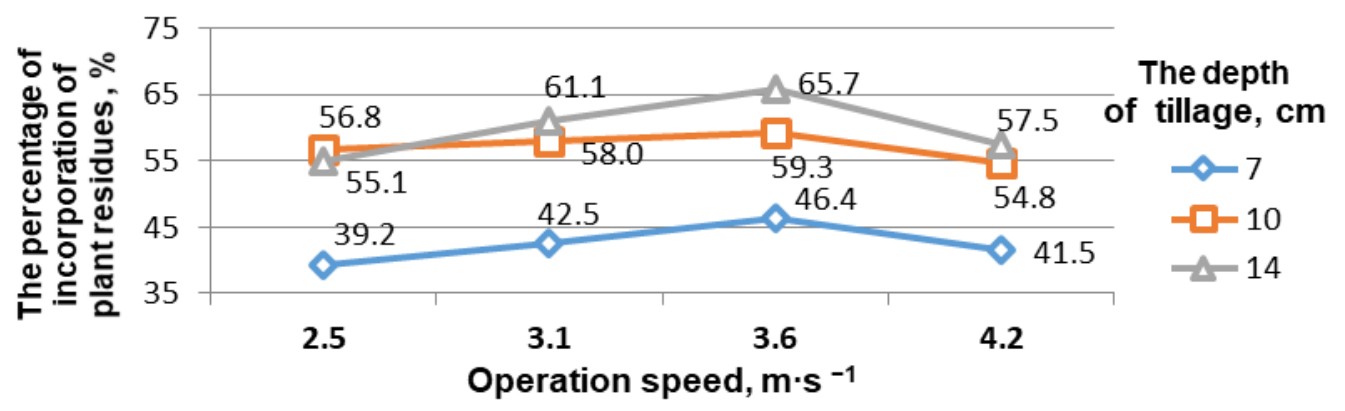

Fig. 3. Dependence of incorporation of plant residues on operation speed of the harrow when moving along a row

For all depths of tillage $(7 \mathrm{~cm}, 10 \mathrm{~cm}, 14 \mathrm{~cm})$ the best incorporating of plant residues $(46.4 \%$, $59.3 \%, 65.7 \%$ ) was recorded at a machine speed of $3.6 \mathrm{~m} \cdot \mathrm{s}^{-1}$, and the worst at speed of $2.5 \mathrm{~m} \cdot \mathrm{s}^{-1}$. These results reflect those of Damanauskas et al., who also determined that increasing of the speed and depth 
of soil cultivation led to an increase in the percentage of incorporated plant residues [13]. The studies conducted by Liu and Kushwaha also indicated that higher speed of tillage operation increase the percentage of residue incorporation [14].

Fig. 4 shows how the degree of incorporation of plant residues changed depending on the operation speed in the direction of movement of the harrow at an angle of $35^{\circ}$ to the row. As it can be seen from the graph, the values of the degree of incorporated plant residues decreased with increasing the speed for all set depths. For all depths of tillage $(7 \mathrm{~cm}, 10 \mathrm{~cm}, 14 \mathrm{~cm})$ the highest degree of incorporation of plant residues $(33.5 \%, 37.8 \%, 20.0 \%)$ was recorded at a machine speed of $2.5 \mathrm{~m} \cdot \mathrm{s}^{-1}$ and the lowest values were observed at a speed of $4.2 \mathrm{~m} \cdot \mathrm{s}^{-1}$.

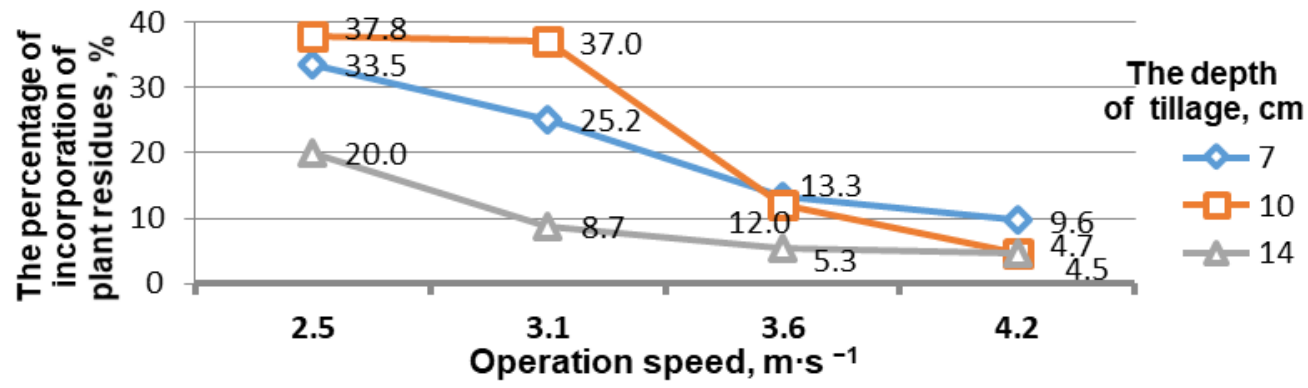

Fig. 4. Dependence of incorporation of plant residues on operation speed of the harrow when moving at an angle of $35^{\circ}$ to a row

It should be noted that when the harrow moved at an angle to the row, all indicators of the quality of the incorporation of plant residues were very low and far from the agricultural requirements. The graphs clearly show that when the machine was moving along the row for all the adjusted depths of cultivation provides a much better incorporation of residues than when moving at an angle to the row.

According to the agricultural requirements, the average height of ridges on the field surface after discing should not exceed $40 \mathrm{~mm}[4 ; 5]$. Fig. 5 shows how the value of this indicator changed depending on the speed in the direction of movement of the harrow along the line. The average height of the ridges decreased with increasing operation speed. For all depths of tillage $(7 \mathrm{~cm}, 10 \mathrm{~cm}, 14 \mathrm{~cm})$ the highest height of ridges $(44.4 \mathrm{~mm}, 51.4 \mathrm{~mm}, 66 \mathrm{~mm})$ was recorded at a harrow speed of $2.5 \mathrm{~m} \cdot \mathrm{s}^{-1}$, and the lowest values were observed at a speed of $4.2 \mathrm{~m} \cdot \mathrm{s}^{-1}(25.8 \mathrm{~mm}, 26.5 \mathrm{~mm}, 43.4 \mathrm{~mm})$. Also Fig. 5 shows that at a speed of $2.5 \mathrm{~m} \cdot \mathrm{s}^{-1}$ at any of the depths of cultivation the agricultural requirements were not met. The same was observed for all speeds at a set depth of cultivation of $14 \mathrm{~cm}$. The best results were achieved only when the depths of $7 \mathrm{~cm}$ were set in the speed range from $3.1 \mathrm{~m} \cdot \mathrm{s}^{-1}$ to $4.2 \mathrm{~m} \cdot \mathrm{s}^{-1}$.

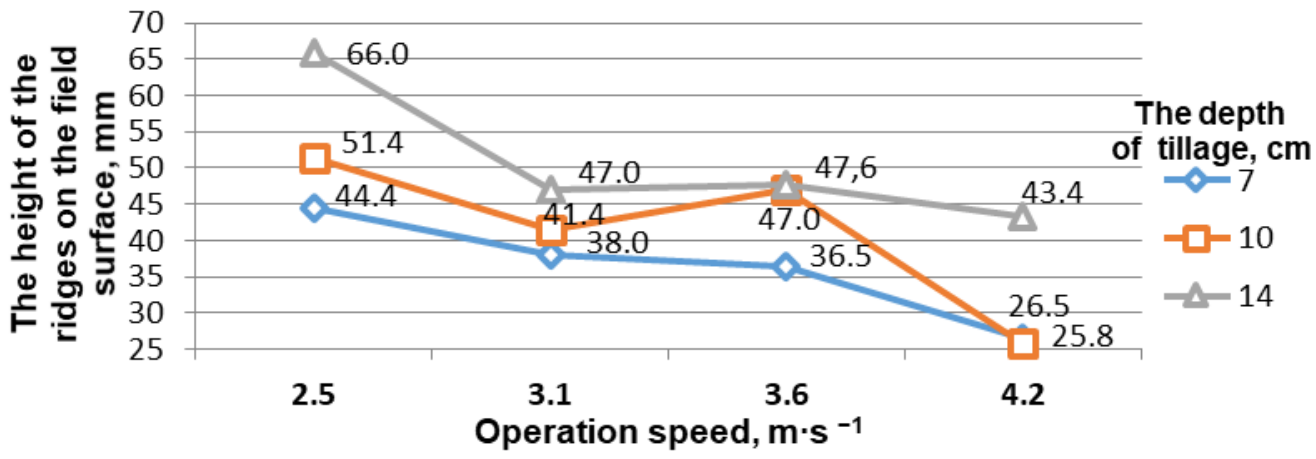

Fig. 5. Dependence of the average height of ridges on the field surface on operation speed of the harrow when moving along a row

Fig. 6 shows the change in the relief of the field surface depending on the operating speed, when the harrow moves at an angle of $35^{\circ}$ to the row. Studies have shown an increase in the average height of the ridges on the field surface with an increase of the adjusted depth of tillage. For tillage depths of $7 \mathrm{~cm}$ and $10 \mathrm{~cm}$, a decrease in the average height of the ridges was observed at the harrow speed from $2.5 \mathrm{~m} \cdot \mathrm{s}^{-}$ ${ }^{1}$ to $3.1 \mathrm{~m} \cdot \mathrm{s}^{-1}$, in other ranges this indicator only increased. For a tillage depth of $14 \mathrm{~cm}$, an increase in the average height of the ridges was observed in the range from $2.5 \mathrm{~m} \cdot \mathrm{s}^{-1}$ to $3.1 \mathrm{~m} \cdot \mathrm{s}^{-1}$, and in other ranges decrease. 
It was possible to ensure compliance with agricultural requirements only at a tillage depth of $7 \mathrm{~cm}$ in the speed range from $3.1 \mathrm{~m} \cdot \mathrm{s}^{-1}$ to $3.6 \mathrm{~m} \cdot \mathrm{s}^{-1}$, as well as at a tillage depth of $10 \mathrm{~cm}$ and a speed of $3.1 \mathrm{~m} \cdot \mathrm{s}^{-1}$

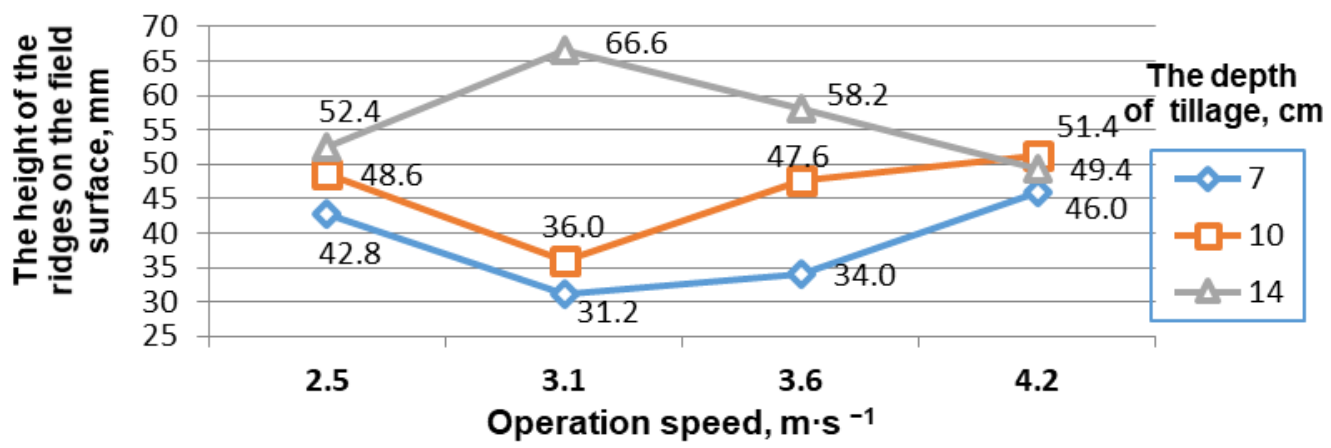

Fig. 6. Dependence of the average height of ridges on the field surface on operation speed of the harrow when moving at an angle of $35^{\circ}$ to a row

Fig. 7 shows that the average height of the ridges at the bottom of the furrow (furrow bottom profile) decreased with increasing speed from $2.5 \mathrm{~m} \cdot \mathrm{s}^{-1}$ to $3.6 \mathrm{~m} \cdot \mathrm{s}^{-1}$, when the harrow moved along the row. When the speed of the machine was $2.5 \mathrm{~m} \cdot \mathrm{s}^{-1}$ at any of the set depths of cultivation, it failed to achieve the agricultural requirements (not more than $50 \mathrm{~mm}[4 ; 5]$ ).

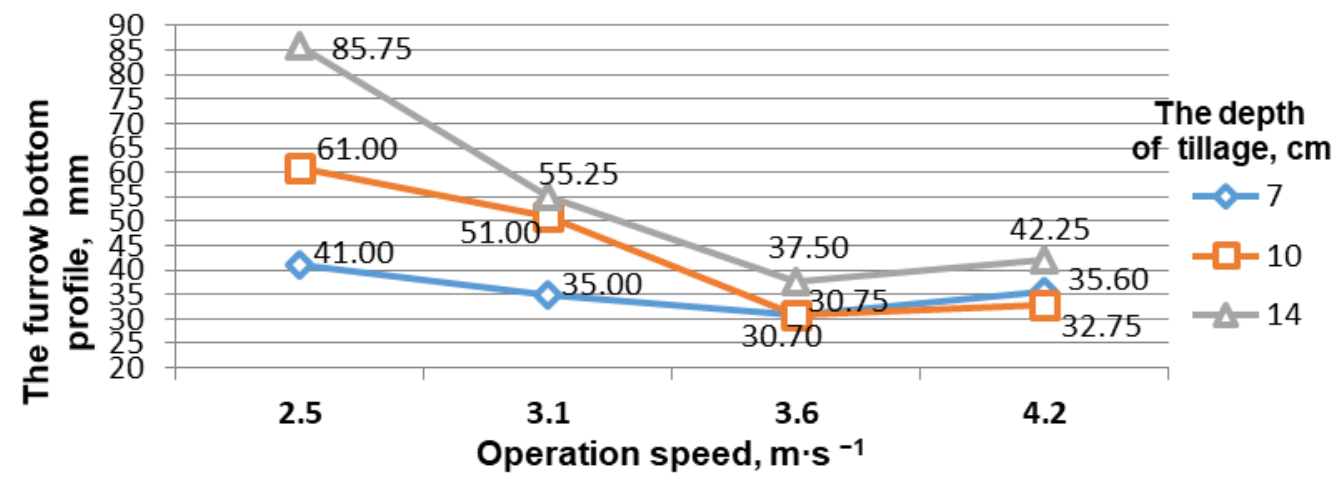

Fig. 7. Dependence of the furrow bottom profile on operation speed of the harrow when moving along a row

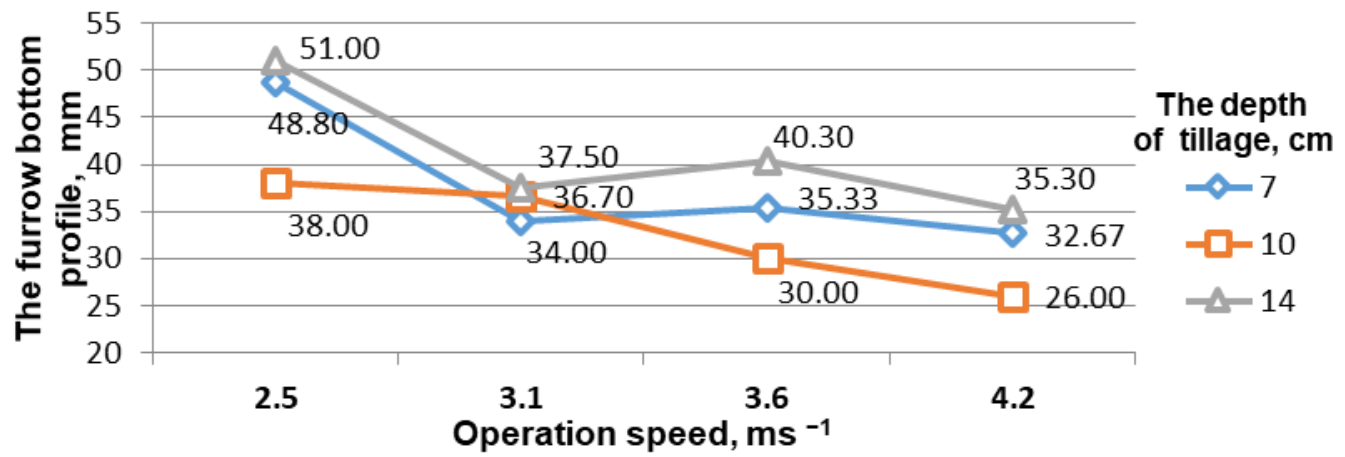

Fig. 8. Dependence of the furrow bottom profile on operation speed of the harrow when moving at an angle of $35^{\circ}$ to a row

When the harrow moved at an angle of $35^{\circ}$ to the row (Fig. 8), it managed to ensure compliance with the agricultural requirements at all set depths and speeds, while when moving along the line it was possible only in the speed range from $3.1 \mathrm{~m} \cdot \mathrm{s}^{-1}$ to $4.2 \mathrm{~m} \cdot \mathrm{s}^{-1}$.

With a set tillage depth of $7 \mathrm{~cm}$ it was possible to comply with the agricultural requirements at all speeds and both directions, except for the speed of $3.1 \mathrm{~m} \cdot \mathrm{s}^{-1}$ during the movement of the harrow along the row. 
When the disc harrow was set to a depth of $14 \mathrm{~cm}$, the best results at all speeds were observed in the direction of movement at an angle of $35^{\circ}$ to the row.

\section{Conclusions}

1. In both directions of the harrow movement the values of deviations from the set depth of tillage did not exceed the established agricultural requirements of $20 \mathrm{~mm}$, except for cultivation to a depth of $14 \mathrm{~cm}$. The smallest deviation (1.4\%) was observed, when the machine was moving along the row at a speed of $3.1 \mathrm{~m} \cdot \mathrm{s}^{-1}$ for a set depth of $10 \mathrm{~cm}$.

2. The highest percentage of the incorporation of plant residues was obtained, when the machine was moving along the row. When the harrow moved at an angle to the row, all indicators of the quality of the incorporation of plant residues were very low and far from the agricultural requirements. For all depths of tillage, when moving along the row, the best incorporation of plant residues (46.4, $59.3 \%, 65.7 \%$ ) was recorded at a machine speed of $3.6 \mathrm{~m} \cdot \mathrm{s}^{-1}$.

3. The lowest average heights of ridges on the field surface were obtained in the speed range from $3.1 \mathrm{~m} \cdot \mathrm{s}^{-1}$ to $4.2 \mathrm{~m} \cdot \mathrm{s}^{-1}$ at a depth of $7 \mathrm{~cm}$ in the case of the harrow movement along the row. It was possible to comply with the agricultural requirements, when the machine was moving at an angle to a row only at a tillage depth of $7 \mathrm{~cm}$ in the speed range from $3.1 \mathrm{~m} \cdot \mathrm{s}^{-1}$ to $3.6 \mathrm{~m} \cdot \mathrm{s}^{-1}$, as well as at a tillage depth of $10 \mathrm{~cm}$ and a speed of $3.1 \mathrm{~m} \cdot \mathrm{s}^{-1}$.

4. The smallest value of the furrow bottom profile was observed, when the harrow moved at an angle of $35^{\circ}$ to the row. The obtained indicators were within the agro requirements at all set depths and speeds. And when the aggregate moved along the row, this was achieved only at the speeds from $3.6 \mathrm{~m} \cdot \mathrm{s}^{-1}$ to $4.2 \mathrm{~m} \cdot \mathrm{s}^{-1}$.

\section{References}

[1] Думич В., Батюк Ю., Падюка Т. Ефективність застосування дискових борін та агрегатів у господарствах різного типу (Efficiency of use of disc harrows and aggregates in farms of different types) Collection of scientific works of UkrNDIPVT named after L. Pogorily. 2015.№ 19 (33). pp. 177-184. (In Ukrainian).

[2] Смолінський С., Марченко В. Фактори, що визначають якість роботи дискових знарядь (Factors that determine the quality of disc tools) Agroexpert, Ukraine, 2016. (In Ukrainian). [online] [11.12.2020] Available at: https://www.agroexpert.ua/ru/faktoriso-viznacaut-akist-robotidiscovihznarad.

[3] Теслюк Г.В., Волик Б.А., Сокол С.П., Кобець О.М., Семенюта А.М. Грунтообробні агрегати на основі дискових робочих органів (Tillage aggregates based on disc working bodies) Monograph, Dnipropetrovsk. 2016. 144 p. (In Ukrainian).

[4] Сохт К.А. Трубилин Е.И., Коновалов В.И. Дисковые бороны и лущильники. Проектирование технологических параметров: учеб. пособие (Disc harrows and cultivators. Design of process parameters: a tutorial) Krasnodar, KubSAU. 2014. 164 p. (In Russian).

[5] Погорілий В. Дослідження ефективності різних типів дискових робочих органів при поверхневому обробітку грунту (Research of efficiency of various types of disc working bodies at surface tillage) Veles-Agro. Ukraine, 2015. (In Ukrainian). [online] [07.12.2020] Available at: http://www.velesagro.com/company/arti cles/2015/07/21/19/.

[6] Дегусаров А., Мазуренко А., Дорошенко К. Вітчизняна техніка для загортання рослинних решток. (Domestic equipment for incorporation of plant residues.) Agricultural sector of Ukraine. 2018. (In Ukrainian). [online] [27.01.2021] Available at: http://agroua.net/technics/articles/index. php?aid $=33$

[7] Amantayev M., Gaifullin G., Kravchenko R. etc. Investigation of the furrow formation by the disc tillage tools. Bulgarian Journal of Agricultural Science, vol. 24(4), 2018, pp. 704-709.

[8] Arvidsson J., Keller T., Gustafsson. K. Specific draught for mouldboard plough, chisel plough and disc harrow at different water contents. Soil \& Tillage Research, vol. 79, 2004, pp. 221-231 doi:10.1016/j.still.2004.07.010

[9] Ahmadi I. A draught force estimator for disc harrow using the laws of classical soil mechanics. Biosyst. Eng., vol.171, 2018, pp. 52-62. doi: 10.1016/j.biosystemseng.2018.04.008 
[10] Godwin R.J., O’Dogherty, M.J. Integrated soil tillage force prediction models. J. Terramechanics, vol. 44, 2007, pp. 3-14. doi: 10.1016/j.jterra.2006.01.001

[11] Kogut Z., Sergiel L., Żurek G. The effect of the disc setup angles and working depth on disc harrow working resistance. Biosystems Engineering vol. 151, 2016, pp. 328-337 doi: 10.1016/j.biosystemseng.2016.10.004

[12] Serrano J.M., Peca J.O., Pinheiro A., Carvalho M., Nunes M., Ribeiro L., Santos F. The effect of gang angle of offset disc harrows on soil tilt, work rate and fuel consumption. Biosystems Engineering. vol. 84, 2003, pp. 171-176 doi: 10.1016/S1537-5110(02)00261-1

[13] Damanauskas V., Velykis A., Satkus A. Efficiency of disc harrow adjustment for stubble tillage quality and fuel consumption. Soil and Tillage Research, vol. 194, 2019. doi: 10.1016/j.still.2019.104311

[14] Liu Y.C., Kushwaha R.L. Effect of tillage speed and straw length on soil and straw movement by a sweep. Soil Tillage Res., vol. 109, 2010, pp. 9-17.

[15] Pires L.F., Borges J.A.R., Rosa J.A., Cooper M., Heck R.J., Passoni S., Roque W.L. Soil structure changes induced by tillage systems. Soil Tillage Res., vol. 165, 2017, pp. 66-79. doi: 10.1016/j.still.2016.07.010

[16] GND 46.16.02.08 - 95 Agricultural machinery. Methods for determining the test conditions.

[17] GD.10.4.2-89. Testing of agricultural machinery. Machines and tools for surface tillage. Test program and methods.

[18] GND.46.16.02.-96. Agricultural machinery. Nomenclature of quality indicators. 